\title{
Limited effectiveness of artificial bird perches for the establishment of seedlings and the restoration of Brazil's Atlantic Forest
}

\author{
Adriana de Almeida ${ }^{a}$, Márcia C.M. Marques ${ }^{\mathrm{b}}$, Marília de Fátima Ceccon-Valente ${ }^{\mathrm{c}}$, \\ José Vicente-Silva ${ }^{\mathrm{d}}$, Sandra Bos Mikich ${ }^{\mathrm{e}, \mathrm{f}, *}$ \\ a Programa de Pós-Graduação em Biologia Animal, Instituto de Biociências, Letras e Ciências Exatas, Universidade Estadual Paulista Júlio de Mesquita Filho, \\ Rua Cristóvão Colombo 2265, 15054-000, São José do Rio Preto, SP, Brazil \\ b Laboratory of Plant Ecology, Department of Botany, Federal University of Paraná, CP: 19031, 81531-980, Curitiba, PR, Brazil \\ c Secretaria Municipal da Saúde, Prefeitura de Curitiba, Rua Francisco Torres 830, 80060-130, Curitiba, PR, Brazil \\ d Instituto Brasileiro do Meio Ambiente e dos Recursos Naturais Renováveis, Trecho 2, Edifício Sede, 70818-900, Brasília, DF, Brazil \\ e Embrapa Florestas, Estrada da Ribeira Km 111, CP: 319, 83411-000, Colombo, PR, Brazil \\ ${ }^{\mathrm{f}}$ Department of Zoology, University of Oxford, South Parks Road, OX1 3PS, Oxford, UK
}

\section{A R T I C L E I N F O}

\section{Article history:}

Received 4 March 2015

Received in revised form 30 August 2016

Accepted 30 August 2016

\section{Keywords:}

Ecological restoration

Frugivory

Induced regeneration

Nucleation

Ornitochory

\begin{abstract}
A B S T R A C T
Brazil's Atlantic Forest biome is severely degraded and fragmented throughout its range. Developing effective techniques to restore pasture and agriculture back to native vegetation is therefore a priority for legal and conservation purposes. In this study, we evaluate the ability of artificial bird perches to enhance the arrival of new seeds and seedling establishment in a degraded, semi-deciduous seasonal portion of the Atlantic Forest in southern Brazil. Specifically, we assess the influence of previous land use and habitat types on the abundance, species richness and ecological traits of bird-dispersed seeds, as well as on seedling establishment. Eight sampling sites were established, each containing one unit with seed traps and restoration plots under artificial perches and one similar unit without the perches. These sites were located in pasture and agriculture, distributed between riparian and sub-montane areas. Monthly sampling was conducted over two years between December 2005 and November 2007, resulting in the evaluation of 25,755 seeds and 56 endozoochoric seed species. The most abundant species were the pioneers Cecropia pachystachya Trécul and Solanum americanum Mill. Experimental units with perches received significantly more seeds than control units. Moreover, seed arrival was higher in sub-montane areas and on former pasture sites. Species richness followed a similar pattern of higher seed arrival, but there was no effect of vegetation type. Ecological characteristics of seeds were associated with land use type: former pastures received more tree seeds and pioneer species than expected by chance. Seedling establishment was very low in all treatments, with only eight seedlings established in perch plots by the end of the experiment. We conclude that despite artificial perches significantly increasing the arrival of endozoochoric seeds onto degraded lands, seedling establishment is drastically limited in these areas, compromising the efficacy of this technique for restoration purposes.
\end{abstract}

(C) 2016 Elsevier GmbH. All rights reserved.

\section{Introduction}

The Atlantic Forest once covered almost the entire extent of the Brazilian coast, covering approximately 150 million ha and reaching into Paraguay and Argentina, but it is now restricted to

\footnotetext{
* Corresponding author at: Embrapa Florestas, Estrada da Ribeira Km 111, CP: 319 , 83411-000, Colombo, PR, Brazil.

E-mail addresses: adri_dealmeida@hotmail.com (A. de Almeida) mmarques@ufpr.br (M.C.M. Marques),fc.marilia@gmail.com (M.d.F. Ceccon-Valente), ze.biologia@gmail.com (J. Vicente-Silva), sandra.mikich@embrapa.br (S.B. Mikich).
}

$11.7 \%$ of its original area (Ribeiro, Metzger, Martensen, Ponzoni, \& Hirota, 2009). Encompassing tropical and subtropical regions along its $29^{\circ}$ of latitudinal range (Ribeiro et al., 2009), the Atlantic Forest is one of largest forests on the planet (da Silva \& Casteleti, 2003). This biome has a variety of forest physiognomies which include semi-deciduous, evergreen, deciduous, sub-montane, and montane forests (Oliveira-Filho \& Fontes, 2000). Due to extensive habitat loss and high concentration of endemic species, Brazil's Atlantic Forest is considered a "biodiversity hotspot" according to Myers and colleagues (Myers, Mittermeier, Mittermeier, da Fonseca, \& Kent, 2000). Great part of the degradation of this forest is owing to land use change into agricultural and pasture fields over the late 20th 
and early 21st centuries. Presently, Brazilian law requires that at least $20 \%$ of the area of private rural lands in this Brazilian biome are preserved with native vegetation (Soares-Filho et al., 2014) and many land owners have to adequate to this situation by restoring portions of their lands.

The slow pace of natural regeneration has led conservationists to use management techniques that accelerate regeneration rates. Some of these methods are based on the concept of the successional mechanism of nucleation (Yarranton \& Morrison, 1974), in which colonizing species recruit at high densities in a cluster which mimics natural successional processes (Corbin \& Holl, 2012). These methods include artificial shelters for animals, soil and seed bank translocation, planting of tree islands, and installation of artificial perches for birds (McClanahan \& Wolfe, 1993; Reis, Bechara, \& Tres, 2010; Zahawi, Holl, Cole, \& Reid, 2013). Restoration strategies based on natural processes (e.g. seed dispersal by animals) can have lower costs since they do not depend on seedling production and plantation. It can also enable surrounding forests to act as seed sources, enhancing natural succession.

Frugivorous birds play a key role in seed dispersal as they can disperse more seeds than any other vertebrate in the Atlantic Forest (Almeida-Neto, Campassi, Galetti, Jordano, \& Oliveira-Filho, 2008). They have the habit of perching on structures to defecate or regurgitate previously ingested seeds (Reis, Bechara, Espíndola, Vieira, \& Souza, 2003). This behavior has been exploited by restoration ecologists through the introduction and maintenance of natural and artificial perches in degraded landscapes (North America: McClanahan and Wolfe, 19933; Central America: Holl, 1998; Shiels \& Walker, 2003; and South America: Zwiener, Cardoso, Padial, \& Marques, 2014).

The effect of bird perches on the arrival of new seeds (seed rain) has been relatively well studied. However, this and similar restoration methods-such as use of essential oils to attract bats (Bianconi, Mikich, Teixeira, \& Maia, 2007; Bianconi, Suckow, CruzNeto, \& Mikich, 2012)-have recently been criticized, as despite increasing seed arrival, they do not necessarily improve seedling establishment or enhance the successional process (Graham \& Page, 2012; Heelemann, Krug, Esler, Reisch, \& Poschlod, 2012; Reid \& Holl, 2013), and some bird assisted restoration studies fail to report the subsequent stages after seed dispersal (i.e. germination, seedling recruitment and survival) (Duncan \& Chapman, 1999; Gonzales, Ingle, Lagunzad, \& Nakashizuka, 2009; McDonnell \& Stiles, 1983).

We aimed to systematically evaluate the effectiveness of artificial bird perches at increasing seed rain and seedling establishment (which includes seed germination) at the same time. We also studied the identity and ecological traits of the seed and seedlings encountered. We conducted the experiment under two land use types commonly found in tropical landscapes-agriculture and pasture-settled in two different forest habitats (riparian and submontane). We hypothesized that (1) seed deposition and seedling establishment (abundance, species density and richness) are higher in areas with bird perches, as found in previous studies; (2) the distribution pattern of seeds is similar for both land use types and habitats; while (3) the distribution pattern of seedlings differs according to land use type and habitat, especially regarding species' richness and ecological traits.

\section{Methods}

\subsection{Study area and sites}

The study took place at Corumbataí farm $\left(23^{\circ} 56^{\prime} 11^{\prime \prime} \mathrm{S}\right.$ and 51 $56^{\prime} 59^{\prime \prime}$ W; $440 \mathrm{~m}$ a.s.l.), municipality of Fênix, Paraná State (Fig. 1). According to an updated version of the Köppen-Geiger classification (Kottek, Grieser, Beck, Rudolf, \& Rubel, 2006), the climate is humid subtropical (Cfa), with hot summers (mean temperature $25^{\circ} \mathrm{C}$ ) and winters with rare frosts (mean temperature $16^{\circ} \mathrm{C}$ ), without a distinct dry season. Mean annual precipitation is $1683 \mathrm{~mm}$ and rain is concentrated during the summer months (Mikich \& de Oliveira, 2003).

The study area was once covered by Semi-deciduous Seasonal Forest, or Interior Forests, one of the vegetation types of the Atlantic Forest biome (see Ledru, Montade, Blanchard, \& Hély, 2016; Ribeiro et al., 2009; da Silva \& Casteleti, 2003). This forest type is largely seasonal and $20-50 \%$ of its trees have deciduous behavior (Instituto Brasileiro de Geografia e Estatística, 2012). Due to intensive human activities, in the past few decades the Semi-deciduous Seasonal Forest has been reduced to small fragments surrounded by agriculture and pasture lands throughout its distribution (Mikich \& Silva, 2001).

In the study region, the Semi-deciduous Seasonal Forest is characterized by two distinct sub-formations: 1) Riparian, distributed alongside the course of the rivers; and, 2) Sub-montane, located at higher altitudes $(50-500 \mathrm{~m}$ ) (Instituto Brasileiro de Geografia e Estatística, 2012). Besides altitude, the main difference between the two sub-formations is the amount of water in the soil: riparian forests are regularly under the influence of rivers' tides and some species, like Sebastiania commersoniana (Baill.) L.B. Sm. \& Downs (Euphorbiaceae), Calliandra foliolosa Benth. (Leguminosae), and Blechnum brasiliense Desv. (Blechnaceae), are adapted to periods of flooding (Bianchini, Popolo, Dias, \& Pimenta, 2003; Mikich and de Oliveira, 2003) while sub-montane species are not. Therefore, although these two sub-formations are similar in species richness ( 82 tree species in riparian and 83 species in sub-montane forests), there are some differences in species composition (about $53 \%$ of tree species are common to both types) (Mikich, Silva, \& de Moura-Britto, 2004).

The Semi-deciduous Seasonal Forest in our study site is characterized by an emergent layer mainly composed by Aspidosperma polyneuron Müll. Arg. (Apocynaceae), Gallesia integrifolia (Spreng.) Harms (Phytolaccaceae), and Ficus spp. (Moraceae), whose individuals can reach up to $40 \mathrm{~m}$ high. The canopy is highly diverse and the main families include Meliaceae, Lauraceae, Leguminosae, and Arecaceae, with Euterpe edulis Mart. as the dominant species. The most common trees in understory are Sorocea bonplandii (Baill.) W.C. Burger, Lanj. \& Wess. Boer, Citrus sinensis (L.) Osbeck, and Trichilia P. Browne. The shrubby-herbaceous vegetation comprises the families Dryopteridaceae, Thelypteridaceae, and Pteridaceae (all ferns), Poaceae, Marantaceae, Piperaceae, and Commelinaceae (Mikich \& de Oliveira, 2003). The threatened animal species (according to IUCN, 2015) Bare-throated Bellbird (Procnias nudicollis [Vieillot, 1817]), Black-backed Tanager (Tangara peruviana [Desmarest, 1806]), Oncilla (Leopardus tigrinus [Schreber, 1775]) and Whitelipped Peccary (Tayassu pecari [Link, 1795]), can be found in the study area.

\subsection{Study design}

To test the effectiveness of artificial perches for restoration purposes, we selected eight open sampling sites located nearby small forest patches. Half of the sites were covered by maize one month before the experiment started and cattle were grazed in the other half. Two sites of Riparian or Submontane forest were used for each former land use type (agriculture or pasture), leading to four treatments (with two replicates per treatment): riparian agriculture; riparian pasture; sub-montane agriculture; and, sub-montane pasture. All sites were located between $800-2100 \mathrm{~m}$ from the largest forest remnant in the study region, the Vila Rica do Espírito Santo State Park (Fig. 1), a protected area of 354 ha that is expected to be an important source of propagules and seed dispersers for the region (Mikich \& de Oliveira, 2003). 


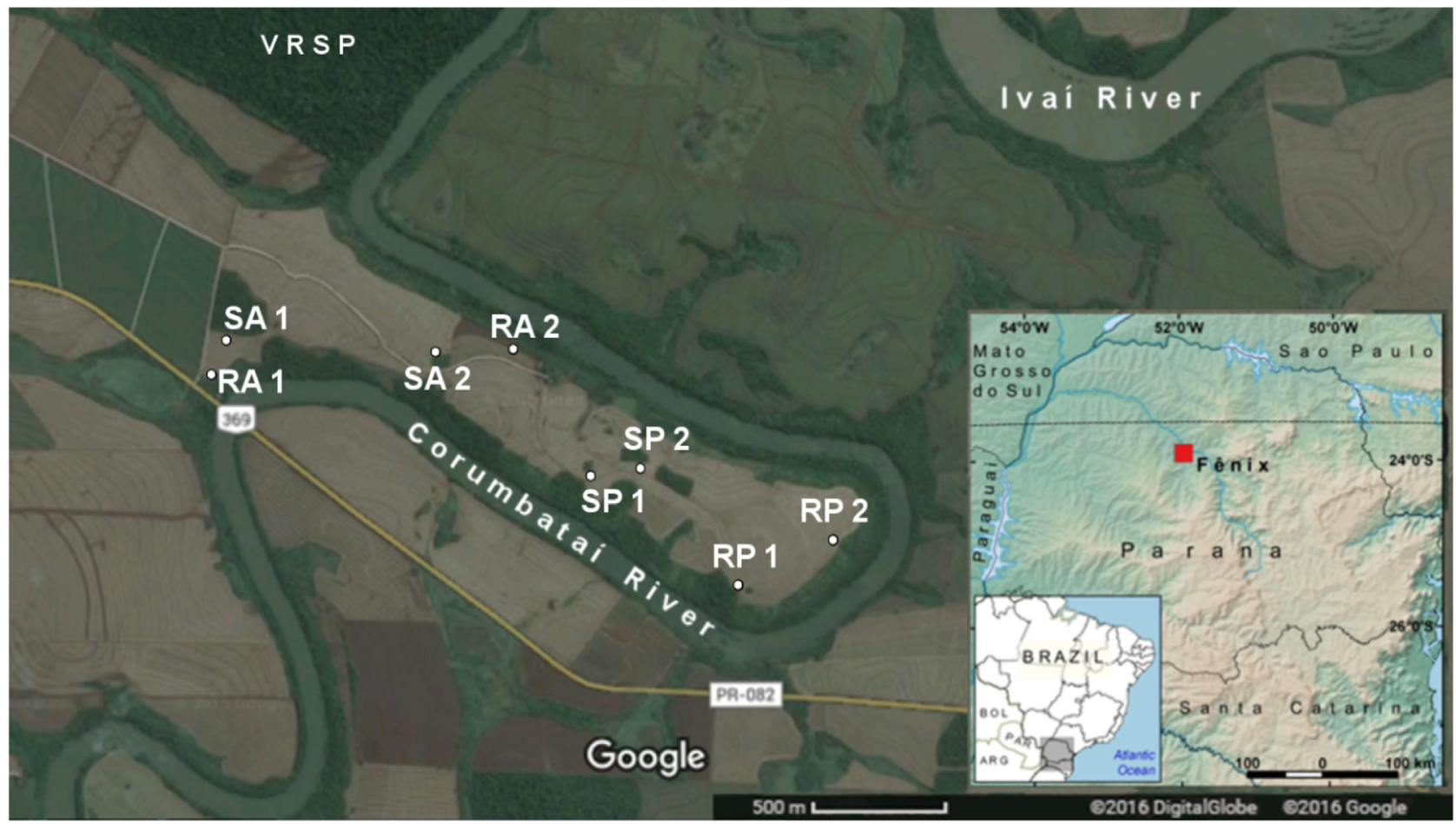

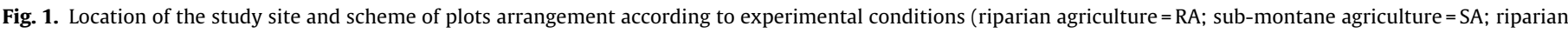

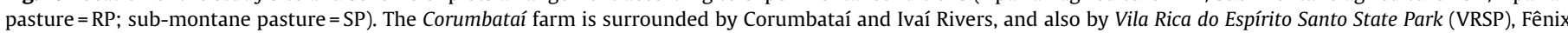
municipality, Paraná State, Southern Brazil. Satellite image from @oGoogle 2016.

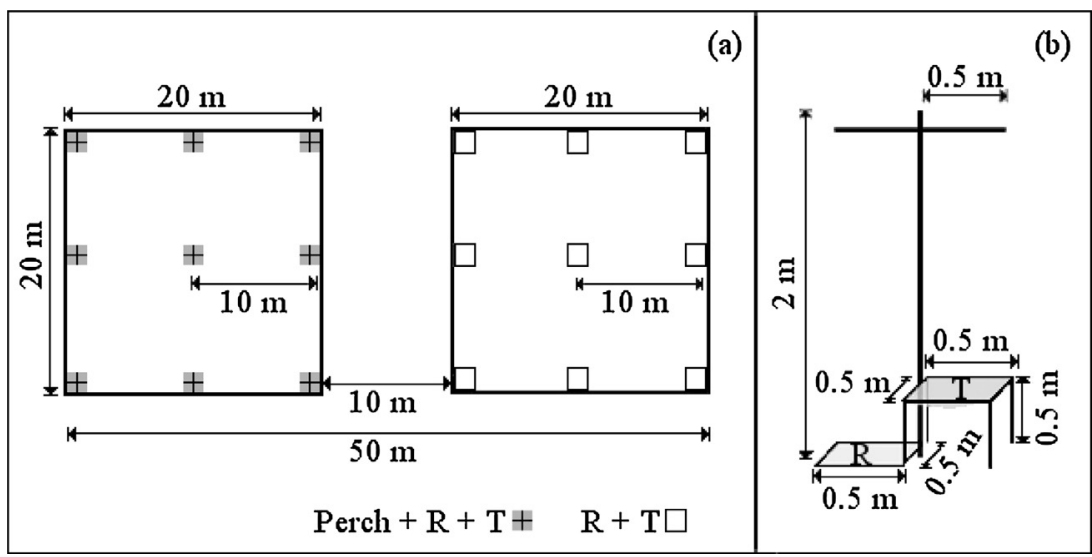

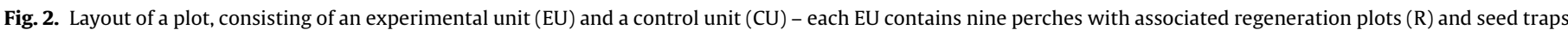
(T), and each CU contains nine R and T under open sky (a); Scheme of a perch, with associated R and T (b).

Each sampling site was divided into two adjacent $20 \times 20 \mathrm{~m}$ units (Fig. 2a): one experimental and one control. The experimental unit comprised nine perches with associated seed traps and seedling emergence subplots (hereafter called "restoration plots"), while the control unit contained no perches above the traps or plots. Bird perching structures consisted of crossbar perches (see Holl, 1998), made with a $2 \mathrm{~m}$ high bamboo pole with a $1 \mathrm{~m}$ long bamboo crossbar at $1.8 \mathrm{~m}$ above the soil. A square seed trap $\left(0.25 \mathrm{~m}^{2}\right)$ made of PVC pipes and $0.5 \mathrm{~mm}$ mesh nylon fabric was placed underneath each perch at an above-ground height of $0.5 \mathrm{~m}$ (Fig. 2b). Next to each seed trap, underneath the other half of the crossbar perch, we set one square restoration plot $\left(0.25 \mathrm{~m}^{2}\right.$; Fig. $\left.2 \mathrm{~b}\right)$.

Pasture sites had been cultivated with the grass Cynodon nlemfuensis Vanderyst for approximately 20 years. At the beginning of the experiment the sampling sites were fenced and cattle were removed. Agriculture sites had been cultivated with soy and maize for the same time period and had been regularly treated with herbicides and insecticides. Crops were removed from the sampling sites at the beginning of the experiment, although surrounding productive areas were left untouched.

\subsection{Data collection}

All traps were emptied at monthly intervals over a two-year period (December 2005-November 2007) when every seedling ( $>2 \mathrm{~cm}$ high) was marked and checked for emergence and survival within the restoration plots. The entire content of each trap was taken to the laboratory where it was oven dried at $60^{\circ} \mathrm{C}$. Seeds were then screened and identified using a seed reference collection from the same study area deposited at the Embrapa's Ecology Lab (Colombo/PR, Brazil). Only seeds with endozoochoric traits (dispersed in the guts of animals) were considered (Howe \& Smallwood, 
1982). Seedlings were identified based on vouchers collected near the restoration plots. Seed and seedling species were then classified according to their life form (herb, liana, shrub or tree) described by Mikich and Silva (2001), and successional group (pioneer and non-pioneer) following Swaine and Whitmore (1988).

\subsection{Data analysis}

For the purpose of analysis, seeds sampled during the two years of the study were grouped for each sample area. Differences among sub-formation type (riparian vs sub-montane), land use type (agriculture $v s$ pasture), and perch use (perch $v$ s control) were tested with a nested factorial ANOVA. For this procedure we considered "land use type" nested in "sub-formation type", and "perch use" nested in both "sub-formation type" and "land use type". In addition, we also considered the "replicate" nested within all the factors described above. Dependent variables were seed abundance and seed species density.

To compare seed species' richness among sampling units (experimental vs control) and among treatments we used sample based rarefaction curves scaled by seed abundance (Colwell, Mao, \& Chang, 2004; Gotelli \& Colwell, 2001). In order to quantify the compositional dissimilarity between riparian and sub-montane experimental units, we used the Bray-Curtis dissimilarity index.

An independence test $\left(\chi^{2}\right)$ was used (Zar, 2010) for comparing the seed distribution (abundance and species density) between different land use types and according to life form (herb, liana, shrub or tree) and successional group (pioneer and non-pioneer).

Nested ANOVA was performed in Statistica 7.0 (StatSoft, Inc, 2004). Rarefaction curves and independence tests were performed in the computing environment $R$ version 3.0.2 (R Core Team, 2013). We used the vegan package (Oksanen et al., 2013) for calculation of rarefaction curves and dissimilarity indices, and the Rcmdr package (Fox, 2005) for the $\chi^{2}$ independence tests. All data was tested for normality.

\section{Results}

Seeds: After two years of the experiment a total of 25,755 seeds with endozoochoric traits were collected from the seed traps. Of these, 95\% were found under the perches (i.e. in the experimental units). Estimated seed density under the perches was 680 seeds $\mathrm{m}^{-2} \mathrm{yr}^{-1}$ compared to 36 seeds $\mathrm{m}^{-2} \mathrm{yr}^{-1}$ in the seed traps from control units.

A total of 56 morphospecies of seeds were found, 47 of which were identified to genus and/or species level (Table 1). Out of all morphospecies, only $61 \%$ occurred under perches. The most numerically abundant species was Cecropia pachystachya Trécul, accounting for $67 \%$ of the total seeds, followed by Solanum americanum Mill. with $10 \%$ and Morus nigra L. with 5\%. Of all identified species ( $N=44), 52 \%$ were trees, $20 \%$ were shrubs, $18 \%$ were lianas and $9 \%$ were herbs. From all classified species, $68 \%$ were pioneers and $32 \%$ were non-pioneers.

There were significant effects of sub-formation type $(F=11.66$, $d f=1, p=0.000)$, land use type $(F=9.96, d f=2, p=0.000)$, perch use $(F=40.16, d f=4, p=0.000)$ and area $(F=21.19, d f=8, p=0.000)$ on seed abundance. On average, seed traps in experimental units contained approximately 19 times more seeds than the control, sub-montane sites had approximately twice as many seeds as riparian sites, and former pasture sites had approximately 1.8 times more seeds than former agriculture sites (Fig. 3a). Similar patterns were observed for seed species density regarding land use type $(F=29.84, d f=2, p=0.000)$, perch use $(F=90.53, d f=4, p=0.000)$ and area $(F=9.07, d f=8, p=0.000)$, with seed traps in experimental units containing approximately four times as many seed species (a)

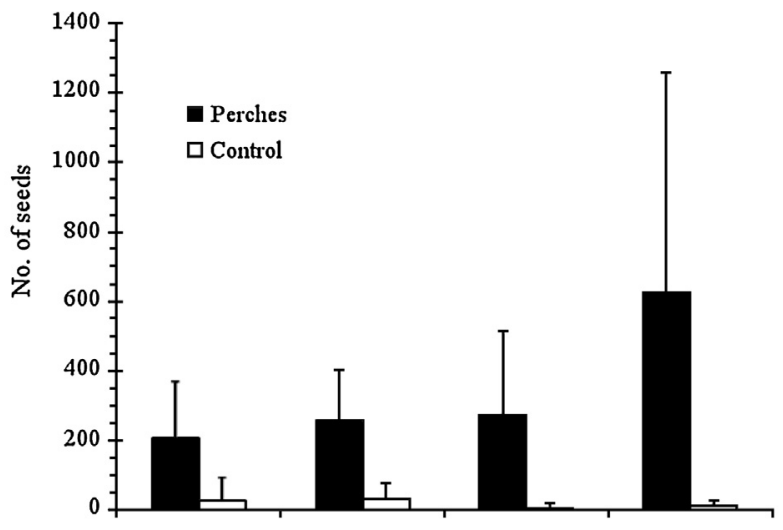

(b)

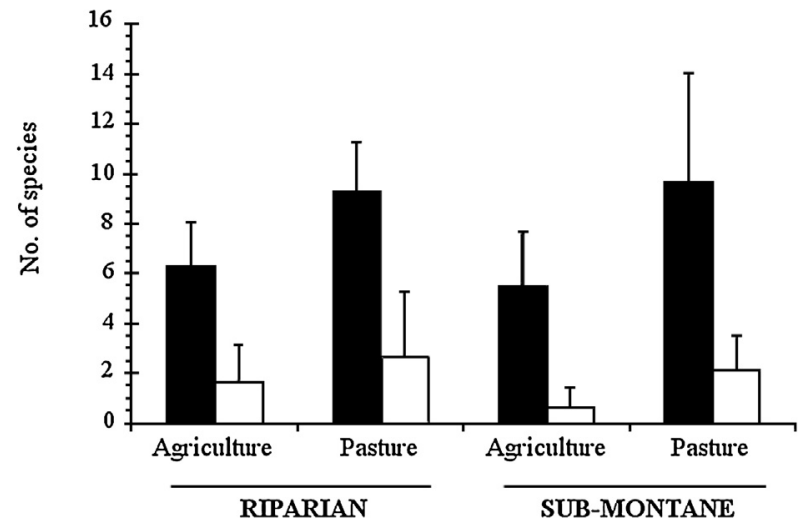

Fig. 3. Average $( \pm S D)$ number of seeds (a) and number of seed species (b) in areas undergoing restoration in Southern Brazil.

as control seed traps. However, no significant effects were found for sub-formation type $(F=2.48, d f=1, p=0.11)$. Seed species density in pasture seed traps was 1.5 times higher than in agriculture seed traps (Fig. 3b). Variation among seed traps was not significant for either seed abundance or species density ( $p=0.60$ and $p=0.95$, respectively), indicating a regular distribution within each sample area.

Seed species richness was significantly higher in the experimental units than in the control units (95\% confidence interval; Fig. 4a). When treatments were compared, pasture had higher seed species richness than agriculture (Fig. 4b). The Bray-Curtis dissimilarity index between riparian and sub-montane experimental units was 0.37 , indicating a high level of similarity of assemblages between the two habitats.

When classified into ecological groups (life form and successional group), the life form of seeds from experimental units was associated with land use type $\left(\chi^{2}=1192.82, d f=3, p=0.000\right.$; Fig. 5a), with more seed abundance of tree species sampled in pasture units than expected by chance; for seed species density, the distribution of life forms was independent $\left(\chi^{2}=0.46, d f=3, p=0.927\right)$. The distribution for successional groups (pioneer $v s$ non-pioneer) for seed abundance from experimental units was significantly associated with land use, with more seeds from pioneer species in pasture units than expected by chance $\left(\chi^{2}=54.84, d f=1, p=0.000\right.$; Fig. $\left.5 b\right)$; seed species density was independently distributed $\left(\chi^{2}=0.06\right.$, $d f=1, p=0.799$ ).

Seedlings: A total of 57 seedlings belonging to 10 species were recorded during the sampling period. In the experimental units, three species (30 individuals) were classified as endozoochoric and 28 individuals potentially derived from seeds of bird perches (Table 2). The species included the exotic pioneer trees Citrus L. and Psidium guajava L., and one unidentified species (sp. 1). Additionally, one seedling of Citrus sp. and one seedling of P. guajava were 
Table 1

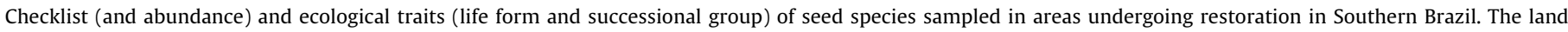

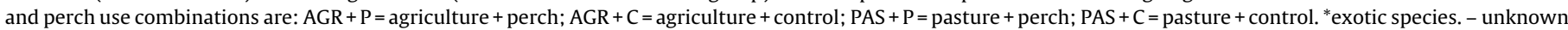
traits.

\begin{tabular}{|c|c|c|c|c|c|c|}
\hline \multirow[t]{2}{*}{ Family/Species } & \multirow[t]{2}{*}{ Life Form } & \multirow[t]{2}{*}{ Successional Group } & \multicolumn{4}{|c|}{ Land and Perch use } \\
\hline & & & $\mathrm{AGR}+\mathrm{P}$ & $\mathrm{AGR}+\mathrm{C}$ & $\mathrm{PAS}+\mathrm{P}$ & $\mathrm{PAS}+\mathrm{C}$ \\
\hline \multicolumn{7}{|l|}{ AMARANTHACEAE } \\
\hline Chamissoa altissima (Jacq.) Kunth & liana & pioneer & 84 & 2 & 63 & 24 \\
\hline \multicolumn{7}{|l|}{ APOCYNACEAE } \\
\hline Tabernaemontana catharinensis A.DC. & tree & pioneer & 0 & 0 & 3 & 0 \\
\hline \multicolumn{7}{|l|}{ ARALIACEAE } \\
\hline Dendropanax cuneatus (DC.) Decne. \& Planch. & tree & pioneer & 21 & 0 & 48 & 0 \\
\hline \multicolumn{7}{|l|}{ ARECACEAE } \\
\hline \multicolumn{7}{|l|}{ BORAGINACEAE } \\
\hline Tournefortia L. & liana & pioneer & 0 & 0 & 21 & 4 \\
\hline Varronia polycephala Lam. & shrub & pioneer & 46 & 0 & 36 & 0 \\
\hline \multicolumn{7}{|l|}{ CANNABACEAE } \\
\hline Trema micrantha (L.) Blume & tree & pioneer & 37 & 1 & 261 & 0 \\
\hline \multicolumn{7}{|l|}{ CUCURBITACEAE } \\
\hline Momordica charantia L. & liana & pioneer & 1 & 0 & 4 & 0 \\
\hline \multicolumn{7}{|l|}{ EUPHORBIACEAE } \\
\hline Alchornea Sw. & tree & pioneer & 14 & 0 & 24 & 0 \\
\hline Tetrorchidium rubrivenium Poepp. & tree & pioneer & 16 & 0 & 0 & 0 \\
\hline \multicolumn{7}{|l|}{ LAURACEAE } \\
\hline Nectandra megapotamica (Spreng.) Mez & tree & non-pioneer & 6 & 0 & 7 & 0 \\
\hline Ocotea Aubl. & tree & non-pioneer & 2 & 0 & 0 & 0 \\
\hline \multicolumn{7}{|l|}{ MELIACEAE } \\
\hline Guarea kunthiana A. Juss. & tree & non-pioneer & 5 & 0 & 1 & 0 \\
\hline G. macrophylla Vahl & tree & non-pioneer & 0 & 0 & 5 & 0 \\
\hline Melia azedarach L. & tree & pioneer & 2 & 0 & 9 & 0 \\
\hline Trichilia elegans A. Juss. & shrub & non-pioneer & 1 & 0 & 0 & 0 \\
\hline T. pallida Sw. & tree & non-pioneer & 0 & 0 & 13 & 0 \\
\hline \multicolumn{7}{|l|}{ MORACEAE } \\
\hline Ficus citrifolia Mill. & tree & non-pioneer & 10 & 0 & 13 & 0 \\
\hline F. eximia Schott & tree & non-pioneer & 25 & 41 & 7 & 0 \\
\hline F. insipida Willd. & tree & pioneer & 0 & 1 & 3 & 2 \\
\hline Maclura tinctoria (L.) D. Don ex Steud. & tree & non-pioneer & 135 & 4 & 505 & 5 \\
\hline *Morus nigra $\mathrm{L}$. & tree & pioneer & 555 & 80 & 442 & 217 \\
\hline \multicolumn{7}{|l|}{ MYRTACEAE } \\
\hline *Psidium guajava L. & tree & pioneer & 35 & 0 & 0 & 0 \\
\hline PASSIFLORACEAE & & & & & & \\
\hline Passiflora L. & liana & pioneer & 0 & 0 & 0 & 1 \\
\hline PHYTOLACCACEAE & & & & & & \\
\hline $\begin{array}{l}\text { Trichostigma octandrum (L.) H. Walter } \\
\text { ROSACEAE }\end{array}$ & liana & pioneer & 57 & 0 & 1 & 0 \\
\hline Rubus urticifolius Poir. & liana & pioneer & 0 & 0 & 12 & 15 \\
\hline RUBIACEAE & & & & & & \\
\hline Geophila macropoda (Ruiz \& Pav.) DC. & herb & non-pioneer & 4 & 0 & 27 & 14 \\
\hline Psychotria carthagenensis Jacq. & shrub & non-pioneer & 0 & 0 & 11 & 0 \\
\hline SAPINDACEAE & & & & & & \\
\hline Allophylus edulis (A.St.-Hil. et al.) Hieron. ex Niederl. & tree & non-pioneer & 1 & 0 & 0 & 0 \\
\hline Cupania vernalis Cambess. & tree & non-pioneer & 1 & 0 & 8 & 0 \\
\hline Paullinia carpopoda Cambess. & liana & non-pioneer & 8 & 0 & 55 & 0 \\
\hline SOLANACEAE & & & & & & \\
\hline Cestrum strigilatum Ruiz \& Pav. & shrub & pioneer & 0 & 0 & 15 & 4 \\
\hline C. corymbosum Schltdl. & shrub & pioneer & 27 & 0 & 68 & 0 \\
\hline Solanum americanum Mill. & herb & pioneer & 301 & 333 & 1883 & 33 \\
\hline S. argenteum Dunal & shrub & pioneer & 8 & 8 & 724 & 6 \\
\hline S. caavurana Vell. & shrub & pioneer & 4 & 6 & 18 & 12 \\
\hline S. sisymbriifolium Lam. & herb & pioneer & 218 & 0 & 146 & 3 \\
\hline Solanum sp.1 & - & pioneer & 0 & 0 & 0 & 23 \\
\hline Solanum sp.2 & - & pioneer & 0 & 1 & 0 & 0 \\
\hline Solanum sp.3 & - & pioneer & 0 & 0 & 3 & 0 \\
\hline S. viarum Dunal & herb & pioneer & 64 & 0 & 0 & 0 \\
\hline
\end{tabular}

URTICACEAE 
Table 1 (Continued)

\begin{tabular}{|c|c|c|c|c|c|c|}
\hline \multirow[t]{2}{*}{ Family/Species } & \multirow[t]{2}{*}{ Life Form } & \multirow[t]{2}{*}{ Successional Group } & \multicolumn{4}{|c|}{ Land and Perch use } \\
\hline & & & $\mathrm{AGR}+\mathrm{P}$ & $\mathrm{AGR}+\mathrm{C}$ & $\mathrm{PAS}+\mathrm{P}$ & $\mathrm{PAS}+\mathrm{C}$ \\
\hline Cecropia glaziovii Snethl. & tree & pioneer & 26 & 0 & 1 & 0 \\
\hline C. pachystachya Trécul & tree & pioneer & 6868 & 77 & 10182 & 130 \\
\hline \multicolumn{7}{|l|}{ VERBENACEAE } \\
\hline Citharexylum solanaceum Cham. & tree & pioneer & 1 & 0 & 78 & 0 \\
\hline Lantana camara L. & shrub & pioneer & 0 & 0 & 310 & 21 \\
\hline L. fucata Lindl. & shrub & pioneer & 33 & 0 & 742 & 236 \\
\hline \multicolumn{7}{|l|}{ VITACEAE } \\
\hline Cissus verticillata (L.) Nicolson \& C.E. Jarvis & liana & pioneer & 1 & 1 & 0 & 0 \\
\hline \multicolumn{7}{|l|}{ UNKNOWN SPECIES } \\
\hline Morphospecies 1 & - & - & 4 & 0 & 13 & 0 \\
\hline Morphospecies 2 & - & - & 0 & 0 & 4 & 0 \\
\hline Morphospecies 3 & - & - & 0 & 0 & 3 & 0 \\
\hline Morphospecies 4 & - & - & 2 & 0 & 1 & 0 \\
\hline Morphospecies 5 & - & - & 0 & 0 & 1 & 0 \\
\hline Morphospecies 6 & - & - & 0 & 0 & 19 & 0 \\
\hline Morphospecies 7 & - & - & 4 & 0 & 11 & 0 \\
\hline Morphospecies 8 & - & - & 0 & 0 & 7 & 0 \\
\hline Morphospecies 9 & - & - & 0 & 0 & 3 & 6 \\
\hline Total & & & 8630 & 555 & 15814 & 756 \\
\hline
\end{tabular}

(a)

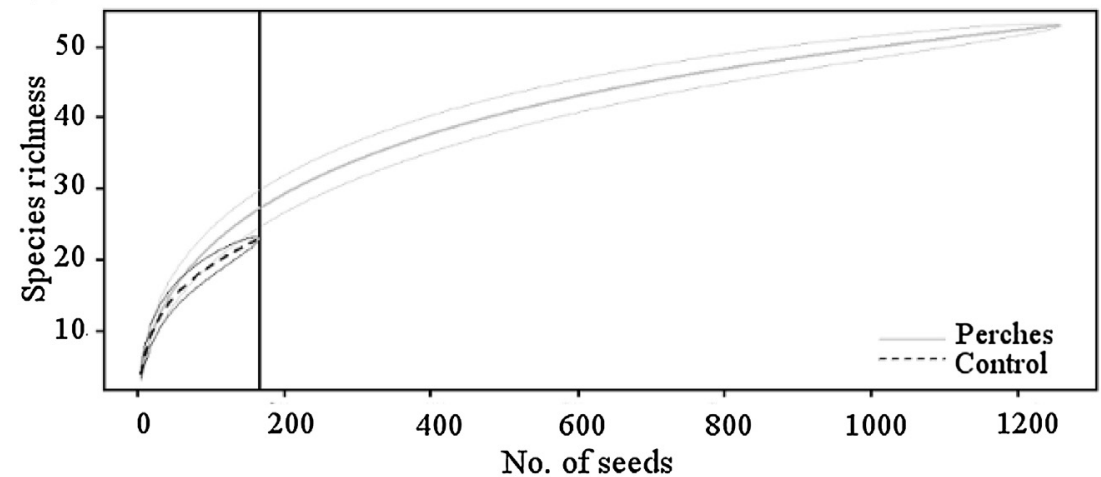

(b)

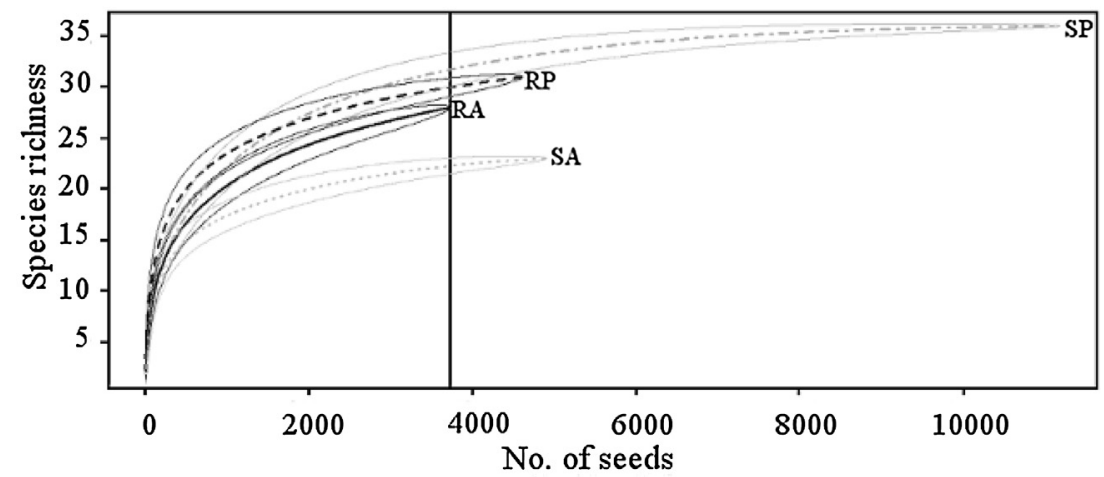

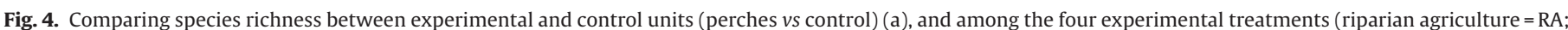

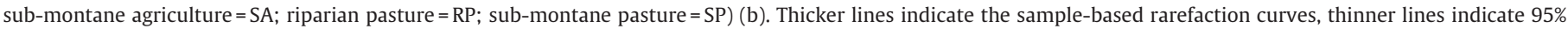
confidence interval and vertical lines indicate points of comparison.

found in control units. Among the 30 seedlings that were derived from endozoochoric species, only 10 survived until the end of the experiment (Table 2). Those that did not survive the full experiment had a mean survival time of approximately nine months. This low number of established seedlings prevented any further statistical analysis on the contribution of bird perches or on the differential effects of treatments.

\section{Discussion}

The use of artificial perches significantly increased the amount of seeds arriving at sites that until recently had been occupied by agriculture or cattle raising activities in an area belonging to the Atlantic Forest biome in southern Brazil. However, a similar effect could not be observed for seedling establishment. 
(a)

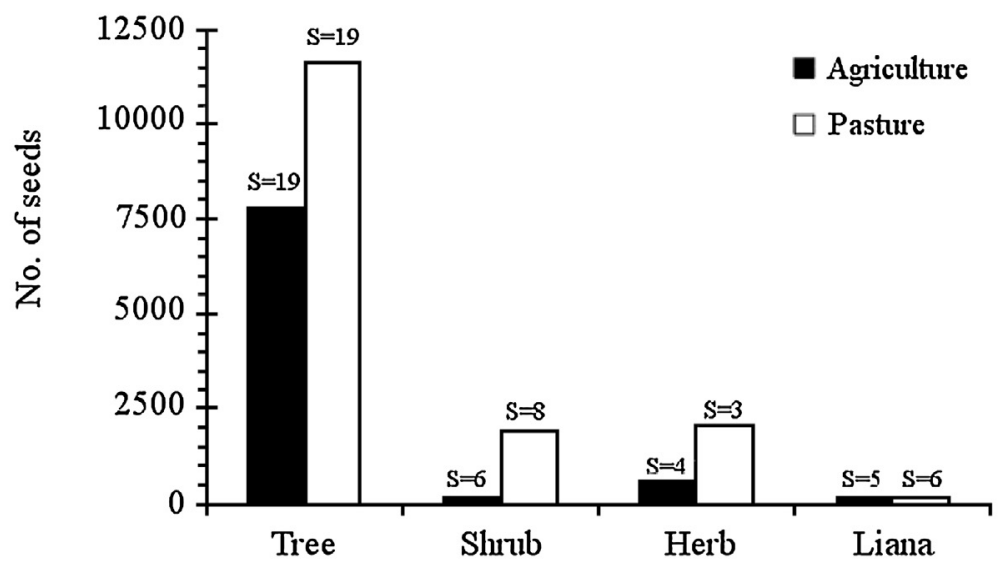

(b)

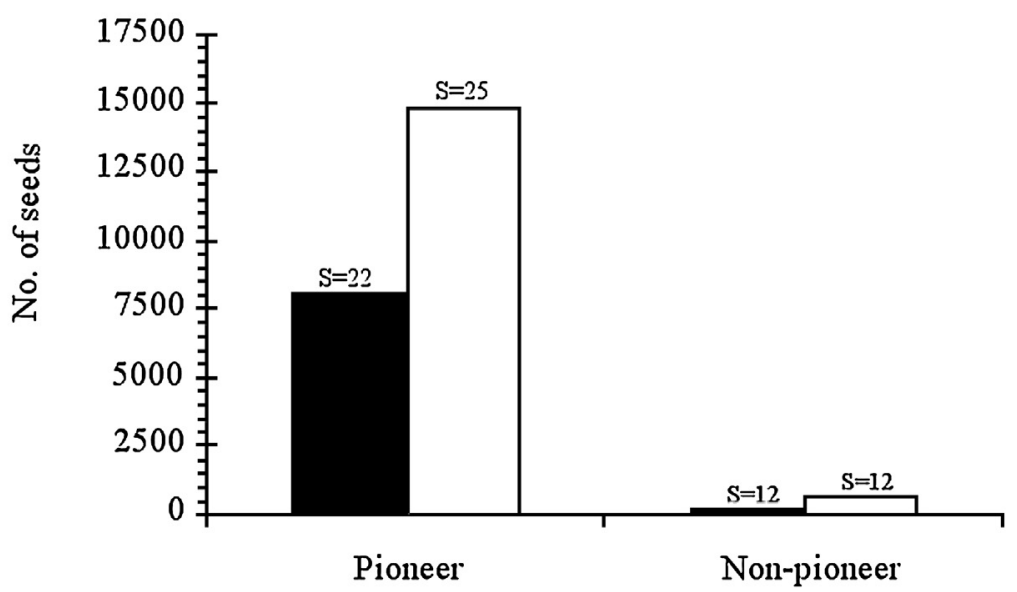

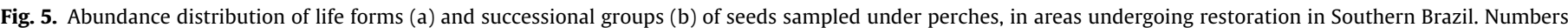

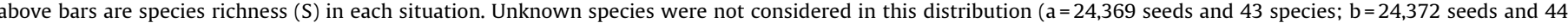
species).

Table 2

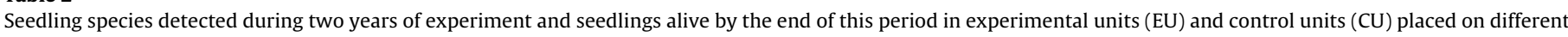
sub-formation and land use types.

\begin{tabular}{|c|c|c|c|c|c|c|}
\hline Sub-formation & Land use & Species & Life Form & $\begin{array}{l}\text { Successional } \\
\text { Group }\end{array}$ & $\begin{array}{l}\text { Number of seedlings } \\
\text { detected }\end{array}$ & $\begin{array}{l}\text { Number of established } \\
\text { seedlings* }\end{array}$ \\
\hline \multicolumn{7}{|l|}{ EU (perch) } \\
\hline \multirow[t]{3}{*}{ Riparian } & \multirow[t]{3}{*}{ Pasture } & Citrus L. & Tree & Pioneer & 1 & 1 \\
\hline & & P. guajava & Tree & Pioneer & 10 & 3 \\
\hline & & Unidentified (sp.1) & - & - & 13 & 2 \\
\hline Sub-montane & Pasture & Unidentified (sp.1) & - & - & 4 & 2 \\
\hline \multicolumn{7}{|l|}{ CU (no perch) } \\
\hline Riparian & Agriculture & P. guajava & Tree & Pioneer & 1 & 1 \\
\hline Sub-montane & Pasture & Citrus sp. & Tree & Pioneer & 1 & 1 \\
\hline
\end{tabular}

* Seedlings still alive by the end of the experiment.

The increase in seed rain provided by perches was 15 times greater in experimental units than in control units at former agriculture sites and 21 times greater in experimental units than in control units at former pasture sites. Species density was also higher under the perches than controls, being three times greater on agriculture sites and 2.5 times greater on pasture sites compared to their respective control units. These results support the previously reported ability of artificial perches to enhance seed rain in areas with low structural complexity, where the addition of seeds can sometimes be 150 times greater than the control (Heelemann et al., 2012; Holl, 1998; Melo et al., 2000).
Seed species density and abundance were affected by subformation type and prior land use type, being highest at sub-montane sites previously used as pastures. Nevertheless, there was a relatively high similarity in seed species arriving in riparian and sub-montane habitats. This compositional correspondence is not likely to be maintained during the regeneration process due to the contrasting biotic and abiotic conditions that influence which species can colonize each area (Cavassani, 2007). Riparian habitats are under direct influence of river tides and this condition alone is expected to limit the survival of some plant species. The higher seed rain (abundance) in sub-montane areas was strongly influenced by 
seeds of $C$. pachystachya that were three times more abundant in sub-montane seed traps $(13,225$ seeds) than riparian seed traps (4032 seeds). Sub-montane and riparian forests differ in species composition, but the observed differences in seed abundance are probably attributable to the high density of this pioneer species in sub-montane regions, or to the close proximity of isolated individuals to the experimental area. It is well known that the distance from forest remnants and the structural complexity of the restoration area can strongly influence the success of the restoration through their influence on the behavior of seed dispersers (McDonnell \& Stiles, 1983; Wunderle, 1997). Nonetheless, as the influence of distance from forest remnants was minimized in the sampling design, it seems likely that the observed differences in the present study are not directly linked to this factor. It is possible that the presence of grasses in the pasture and the spontaneous regeneration of herbs and small shrubs could increase bird activity (pers. obs.), enhancing the quality of perching areas relative to those in former agriculture sites.

Existing vegetation can affect the recruitment of new individuals by its influence on frugivorous bird movements-due to the availability of perching structures, shelter and food provided by the vegetation-and, by extension, seed dispersal patterns (McDonnell \& Stiles, 1983). The diversity and the abundance of species located on forest remnant edges that act as seed sources may also affect propagule consumption and dispersal by birds. This is because zoochoric species located on forest edges have higher probability of being consumed than those occupying the forest interior (Galetti, Alves-Costa, \& Cazetta, 2003). Cecropia pachystachya, S. americanum and S. caavurana Vell. are some of the species that had the highest recorded seed abundances in perch plots (accounting for $77 \%$ of the total seed abundance), and are also characteristic of young successional areas and forest edges (Mikich \& Silva, 2001).

Seed species with different ecological traits were observed in both land use types, although most seeds were from pioneer trees and shrubs. Tropical species with these attributes are particularly important for the restoration of degraded lands (Uhl, Clark, Dezzeo, \& Maquirino, 1988). Specifically, heliophily traits and rapid growth (Swaine \& Whitmore, 1988) can promote the establishment of small aggregates of vegetation (Yarranton \& Morrison, 1974), which can act as a starting point for succession on open land. Fruiting plants are especially important in this sense, since they can attract more birds and bats into these areas undergoing restoration, which will further improve the seed rain and seed bank (GalindoGonzález, Guevara, \& Sosa, 2000; Zwiener et al., 2014). Fruits of Moraceae and Solanaceae, which include some of the most abundant seed species recorded, are frequently consumed by birds and bats in the study area (Bianconi et al., 2012; Mikich, 2001, 2002a, 2002b). Frugivorous bats such as the Seba's Short-tailed Bat (Carollia perspicillata [Linnaeus, 1758]) and the Great Fruit-eating Bat (Artibeus lituratus [Olfers, 1818]) are commonly found in the study area (Bianconi, Mikich, \& Pedro, 2004), and so are the bird dispersers, the Great Kiskadee (Pitangus sulphuratus [Linnaeus, 1766]), the Shiny Cowbird (Molothrus bonariensis [Gmelin, 1789]) and the Smooth-billed Ani (Crotophaga ani [Linnaeus, 1758]) (Mikich et al. in prep.). Small quantities of seeds of non-pioneer species were also found which, although unlikely to thrive on open land, are very important for the later stages of succession (Duncan \& Chapman, 2002). Seeds of some of the most common and important nonpioneer trees found in a 400-year-old secondary forest close to the experimental area were found in the traps: Euterpe edulis Mart., Nectandra megapotamica (Spreng.) Mez, and Guarea kunthiana A. Juss. (Mikich \& Silva, 2001).

Primary and secondary species are both key in the regeneration of a degraded area (Florentine \& Westbrooke, 2004); especially those capable of bearing fruits that can attract more dispersers to the area and ameliorate the seed rain. Seed rain can be the pri- mary source of propagules in extremely disturbed environments (Duncan \& Chapman, 1999; Uhl, Buschbacher, \& Serrao, 1988; Uhl, 1987) and the main source of new individuals in areas that have had their seed bank depleted-as is normally the case when native vegetation has been converted into agriculture or pasture (Cubiña \& Aide, 2001).

Despite this marked success in overcoming seed dispersal limitation into open areas, bird perches appear not to be effective at promoting the next stage of succession. During the two years of the study, the number of seedlings establishing in the experimental sites was extremely low in relation to the number of seeds arriving at the same areas, especially in the agriculture sites. Indeed, the number of successfully established seedlings was so low that it was not even possible to make statistical inferences.

The lack of seedling emergence indicates the existence of some important barriers that may be preventing seedling establishment. We have no definitive evidence for what these barriers may be, though previous studies of degraded areas have identified soil compaction, lack of soil nutrients, competition with grasses, and seed/seedling predation as being unfavorable for seedling establishment (Florentine \& Westbrooke, 2004). Seeds can be predated by insects, fungal pathogens or even rodents in open lands (Cole, 2009). Those that manage to germinate usually face high rates of herbivory in these habitats (Nepstad, Uhl, Pereira, \& Da Silva, 1996). In order to develop an effective restoration program for Atlantic Forest land degraded by agriculture and cattle grazing, it is therefore imperative to further investigate what the main barriers affecting seed germination and seedling establishment in these areas are.

In conclusion, we demonstrate that even though artificial bird perches significantly increase seed rain and have the advantage of being a low cost and low tech option for restoration, their effectiveness is negligible in the fragmented and degraded system we studied. Low levels of seedling emergence in contrast to high levels of seed rain strongly suggest that the biophysical consequences of environmental degradation significantly limit the potentially positive effects of the perches on regeneration. Throughout the Neotropical region, a great fraction of the original forested ecosystems has been converted into pasture or agricultural land (Aide et al., 2013), indicating our results are potentially applicable to a broader geographical range. Considering the current scenario of degraded lands in the highly threatened Atlantic Forest, future studies should therefore focus on the factors that promote or inhibit germination and the establishment of individuals derived from the ornitochoric seed rain.

This experimental approach is quite comprehensive as it evaluates perch effectiveness not only in terms of seed and seedling abundances, but it also considers species richness and their ecological traits. Knowing the seed species that arrive and are recruited in degraded sites is valuable information for restoration purposes and has been neglected in most bird perch studies so far.

\section{Acknowledgements}

This study was developed with financial support of EMBRAPA (02.03.2.011.0). We are in debt to Gledson Bianconi, who coordinated all field activities and was restless to provide the necessary conditions for making this and other simultaneous studies viable, and to Rogério Bittencourt, the owner of Corumbataí Farm, who authorized us to use and modify his land. We thank André Cavassani for field assistance. AA received undergraduate scholarship (process 108278/2008-5) and SBM (process 308419/2008-1) and MCMM (process 304650/2012-9) received productivity grants from CNPq. Dr Richard Ladle and Elisabeth $\mathrm{H}$. Raine revised the final version of the English manuscript. 


\section{References}

Aide, T. M., Clark, M. L., Grau, H. R., Lopez-Carr, D., Levy, M. A., Redo, D., .. \& \& Muñiz, M. (2013). Deforestation and reforestation of Latin America and the Caribbean (2001-2010). Biotropica, 45(2), 262-271.

Almeida-Neto, M., Campassi, F., Galetti, M., Jordano, P., \& Oliveira-Filho, A. (2008). Vertebrate dispersal syndromes along the Atlantic forest: Broad-scale patterns and macroecological correlates. Global Ecology and Biogeography, 17(4), 503-513.

Bianchini, E., Popolo, R. S., Dias, M. C., \& Pimenta, J. A. (2003). Diversidade e estrutura de especies arbóreas em área alagável do município de Londrina, sul do Brasil. Acta Botanica Brasilica, 17(3), 405-419.

Bianconi, G. V., Mikich, S. B., \& Pedro, W. A. (2004). Diversidade de morcegos (Mammalia, Chiroptera) em remanescentes florestais do município de Fênix, noroeste do Paraná, Brasil. Revista Brasileira de Zoologia, 21(4), 943-954.

Bianconi, G. V., Mikich, S. B., Teixeira, S. D., \& Maia, B. H. L. N. S. (2007). Attraction of fruit-eating bats with essential oils of fruits: A potential tool for forest restoration. Biotropica, 39(1), 136-140.

Bianconi, G. V., Suckow, U. M. S., Cruz-Neto, A. P., \& Mikich, S. B. (2012). Use of fruit essential oils to assist forest regeneration by bats. Restoration Ecology, 20(2), 211-217.

Cavassani, A. T. (2007). Floresta estacional semidecidual da bacia do médio rio Ivaí-PR: um estudo da dinâmica de regeneração e o potencial uso das espécies na restauração de ecossistemas. Universidade Federal do Paraná, Curitiba, Brazil. $81 \mathrm{pp}$.

Cole, R. J. (2009). Postdispersal seed fate of tropical montane trees in an agricultural landscape, Southern Costa Rica. Biotropica, 41(3), 319-327.

Colwell, R. K., Mao, C. X., \& Chang, J. (2004). Interpolating, extrapolating, and comparing incidence-based species accumulation curves. Ecology, 85(10), $2717-2727$

Corbin, J. D., \& Holl, K. D. (2012). Applied nucleation as a forest restoration strategy. Forest Ecology and Management, 265, 37-46.

Cubiña, A., \& Aide, T. M. (2001). The effect of distance from forest edge on seed rain and soil seed bank in a tropical pasture. Biotropica, 33(2), 260-267.

da Silva, J. M. C., \& Casteleti, C. H. M. (2003). Status of the biodiversity of the Atlantic Forest of Brazil. In C. Galindo-Leal, \& I. G. Câmara (Eds.), The Atlantic Forest of South America: biodiversity status, threats, and outlook (pp. 43-59). Washington: CABS and Island Press.

Duncan, R. S., \& Chapman, C. A. (1999). Seed dispersal and potential forest succession in abandoned agriculture in tropical Africa. Ecological Applications 9(3), 998-1008.

Duncan, R. S., \& Chapman, C. A. (2002). Limitations of animal seed dispersal for enhancing forest succession on degraded lands. In D. J. Levey, W. R. Silva, \& M Galetti (Eds.), Seed dispersal and frugivory: ecology, evolution and conservation (3rd ed., pp. 437-450). Wallingford: CABI Publishing.

Florentine, S. K., \& Westbrooke, M. E. (2004). Restoration on abandoned tropical pasturelands-Do we know enough? Journal for Nature Conservation, 12(2), $85-94$

Fox, J. (2005). The R commander: A basic statistics graphical user interface to R. Journal of Statistical Software, 14(9), 1-42.

Galetti, M., Alves-Costa, C. P., \& Cazetta, E. (2003). Effects of forest fragmentation, anthropogenic edges and fruit colour on the consumption of ornithocoric fruits. Biological Conservation, 111(2), 269-273.

Galindo-González, J., Guevara, S., \& Sosa, V. J. (2000). Bat- and bird-generated seed rains at isolated trees in pastures in a tropical rainforest. Conservation Biology, 14(6), 1693-1703.

Gonzales, R. S., Ingle, N. R., Lagunzad, D. A., \& Nakashizuka, T. (2009). Seed dispersal by birds and bats in lowland Philippine forest successional area. Biotropica, 41(4), 452-458

Gotelli, N. J., \& Colwell, R. K. (2001). Quantifying biodiversity: Procedures and pitfalls in the measurement and comparison of species richness. Ecology Letters, 4(4), 379-391.

Graham, L. L. B., \& Page, S. E. (2012). Artificial bird perches for the regeneration of degraded Tropical Peat Swamp Forest: A restoration tool with limited potential. Restoration Ecology, 20(5), 631-637.

Heelemann, S., Krug, C. B., Esler, K. J., Reisch, C., \& Poschlod, P. (2012). Pioneers and perches - Promising restoration methods for degraded renosterveld habitats? Restoration Ecology, 20(1), 18-23

Holl, K. D. (1998). Do bird perching structures elevate seed rain and seedling establishment in abandoned tropical pasture? Restoration Ecology, 6(3), 253-261.

Howe, H. F., \& Smallwood, J. (1982). Ecology of seed dispersal. Annual Review of Ecology and Systematics, 13(1982), 201-228.

IUCN. (2015). The IUCN red list of threatened species. version 2015-4.. Downloaded on 01 June 2016. http://www.iucnredlist.org

Instituto Brasileiro de Geografia e Estatística. (2012). Manual técnico da vegetação brasileira ( $2^{\mathrm{a}}$ ed.). Rio de Janeiro: IBGE.

Kottek, M., Grieser, J., Beck, C., Rudolf, B., \& Rubel, F. (2006). World map of the Köppen-Geiger climate classification updated. Meteorologische Zeitschrift, 15(3), 259-263.

Ledru, M.-P., Montade, V., Blanchard, G., \& Hély, C. (2016). Long-term spatial changes in the distribution of the Brazilian Atlantic Forest. Biotropica, 48(2), 159-169.
McClanahan, T. R., \& Wolfe, R. W. (1993). Accelerating forest succession in a fragmented landscape: The role of birds and perches. Conservation Biology, $7(2), 279-288$.

McDonnell, M. J., \& Stiles, E. W. (1983). The structural complexity of old field vegetation and the recruitment of bird-dispersed plant species. Oecologia, 56(1), 109-116.

Melo, V. A., Griffith, J. J., De Marco, P., Jr., Silva, E., Souza, A., Guedes, M. C., \& Ozório T. F. (2000). Efeito de poleiros artificiais na dispersão de sementes por aves. Revista Árvore, 24(3), 235-240.

Mikich, S. B., \& Silva, S. M. (2001). Composição florística e fenologia das espécies zoocóricas de remanescentes de floresta estacional semidecidual no centro-oeste do Paraná, Brasil. Acta Botânica Brasilica, 15(1), 89-113.

Mikich, S. B., \& de Oliveira, K. L. (2003). Revisão do plano de manejo do Parque Estadual Vila Rica do Espírito Santo, Fênix-PR. Curitiba/PR: Mater Natura Instituto de Estudos Ambientais/Fundo Nacional do Meio Ambiente.

Mikich, S. B., Silva, S. M., \& de Moura-Britto, M. (2004). O projeto Malha Florestal e o papel das unidades de conservação na manutenção da Floresta Estacional Semidecidual no Estado do Paraná, Brasil. Pp. 260-270 Congresso Brasileiro de Unidades de Conservação. Fundação O Boticário de Proteção à Natureza, Curitiba.

Mikich, S. B. (2001). Frugivoria e dispersão de sementes em uma pequena reserva isolada do Estado do Paraná, Brasil. Universidade Federal do Paraná

Mikich, S. B. (2002a). A dieta dos morcegos frugívoros (Mammalia, Chiroptera, Phyllostomidae) de um pequeno remanescente de Floresta Estacional Semidecidual do sul do Brasil. Revista Brasileira de Zoologia, 19(1), 239-249.

Mikich, S. B. (2002b). A dieta frugívora de Penelope superciliaris (Cracidae) em remanescentes de floresta estacional semidecidual no centro-oeste do Paraná, Brasil e sua relação com Euterpe edulis (Arecaceae). Ararajuba, 10(2), 207-217.

Myers, N., Mittermeier, R. A., Mittermeier, C. G., Da Fonseca, G. A. B., \& Kent, J. (2000). Biodiversity hotspots for conservation priorities. Nature, 403, 853-858.

Nepstad, D. C., Uhl, C., Pereira, C. A., \& da Silva, J. M. C. (1996). A comparative study of tree establishment in abandoned pasture and mature forest of eastern Amazonia. Oikos, 76(1), 25-39.

Oksanen, J., Blanchet, F. G., Kindt, R., Legendre, P., Minchin, P. R., O’Hara, R.B., ... Wagner, H. (2013). Vegan: Community Ecology Package R package version 2.0-9. Retrieved from: http://CRAN.R-project.org/package=vegan.

Oliveira-Filho, A. T., \& Fontes, M. A. L. (2000). Patterns of Floristic Differentiation among Atlantic Forests in Southeastern Brazil and the influence of climate. Biotropica, 32(4b), 793-810.

R Core Team. (2013). R: A language and environment for statistical computing. Vienna, Austria: R Foundation for Statistical Computing. Retrieved from. http:/ www.r-project.org/

Reid, J. L., \& Holl, K. D. (2013). Arrival $\neq$ survival. Restoration Ecology, 21(2), $153-155$

Reis, A., Bechara, F. C., Espíndola, M. B., Vieira, N. K., \& de Souza, L. L. (2003). Restoration of damaged land areas: Using nucleation to improve successional processes. Natureza \& Conservação, 1(1), 85-92.

Reis, A., Bechara, F. C., \& Tres, D. R. (2010). Nucleation in tropical ecologica restoration. Scientia Agricola, 67(2), 244-250.

Ribeiro, M. C., Metzger, J. P., Martensen, A. C., Ponzoni, F. J., \& Hirota, M. M. (2009). The Brazilian Atlantic Forest: How much is left, and how is the remaining forest distributed? Implications for conservation. Biological Conservation, 142(6), 1141-1153.

Shiels, A. B., \& Walker, L. R. (2003). Bird perches increase forest seeds on Puerto Rican landslides. Restoration Ecology, 11(4), 457-465.

Soares-Filho, B., Rajão, R., Macedo, M., Carneiro, A., Costa, W., Coe, M., . . \& \& Alencar, A. (2014). Cracking Brazil's forest code. Science, 344, 363-364.

StatSoft, Inc. (2004). STATISTICA (data analysis software system), version 7.0. www.statsoft.com

Swaine, M. D., \& Whitmore, T. C. (1988). On the definition of ecological species groups in tropical rain forests. Vegetatio, 75(1-2), 81-86.

Uhl, C., Buschbacher, R., \& Serrao, E. A. S. (1988). Abandoned pastures in eastern Amazonia. I. Patterns of plant succession. Journal of Ecology, 76(3), 663-681.

Uhl, C., Clark, K., Dezzeo, N., \& Maquirino, P. (1988). Vegetation dynamics in Amazonian treefall gaps. Ecology, 69(3), 751-763.

Uhl, C. (1987). Factors controlling succession following slash-and-burn agriculture in Amazonia. Journal of Ecology, 75(2), 377-407.

Wunderle, J. M., Jr. (1997). The role of animal seed dispersal in accelerating native forest regeneration on degraded tropical lands. Forest Ecology and Management, 99(1-2), 223-235.

Yarranton, G. A., \& Morrison, R. G. (1974). Spatial dynamics of a primary succession: Nucleation. Journal of Ecology, 62(2), 417-428.

Zahawi, R. A., Holl, K. D., Cole, R. J., \& Reid, J. L. (2013). Testing applied nucleation as a strategy to facilitate tropical forest recovery. Journal of Applied Ecology, 50(1), 88-96.

Zar, J. H. (2010). Biostatistical analysis (5th ed.). Upper Saddle River, New Jersey: Prentice Hall.

Zwiener, V. P., Cardoso, F. C. G., Padial, A. A., \& Marques, M. C. M. (2014). Disentangling the effects of facilitation on restoration of the Atlantic Forest. Basic and Applied Ecology, 15(1), 34-41. 